\title{
Whole Genome Sequencing of Children's DNA for Research: Points to Consider
}

\section{Kristien Hens}

Health, Ethics \& Society, P.O. Box 616, 6200 MD Maastricht, The Netherlands

Techniques to sequence the entire exome or even genome of an individual are evolving rapidly. Experts believe that in the future it will be possible to sequence the whole genome of an individual for a thousand dollars or less [1]. The advent of cost-effective sequencing techniques opens many possibilities for genetic diagnostics and screening. Furthermore, genetic research will also benefit greatly [2]. For example, research on the genetic component of Autism Spectrum Disorder could take a huge leap forward, as the genes contributing to this disorder are believed to be located throughout the genome [3].

Genetic research on extracted DNA from children has proven to be necessary and fruitful. Such research can focus on specific childhood diseases but can also take the form of longitudinal cohort studies, where children are followed for several years to match genotypical and phenotypical data. The ethical issues raised by the participation of children in genetic research are not analogous to those raised by adult participation, nor do they correspond completely to those raised by the participation of children in clinical trials. These issues include questions about risks and benefits, the scope of parental consent and the return of individual research results $[4,5]$.

With the advent of affordable techniques for whole genome sequencing, research on extracted DNA may eventually become obsolete. The use of whole genome sequencing of the DNA of adults is already the subject of some ethical discussion [6-9]. Also the use of whole genome sequencing in minors for screening and diagnostics purposes is not imaginary. For example, The US President's Council for Bioethics argues that newborn full genome sequencing will eventually replace newborn screening using blood spot cards, thus paving the way for personalized medicine from birth onwards [10]. But the ethical issues to be solved with regard to the sequencing of children's DNA in general and the use of these data for research are not the same as those related to traditional biobank research, as we are now dealing with readily available digitalized data. Nor are they the same as those raised by the sequencing of an adult's entire genome, as a child cannot autonomously consent to the use of his or her DNA for sequencing.

Basically, I believe at least four specific questions related to the participation of children in research involving whole genome sequencing need to be addressed. The first one is related to the issue of solidarity. It is now generally assumed that children can be asked to participate in medical research. In the context of biobanks, the principle of solidarity is often quoted [11]. However, the duty to participate is restricted in the case of children because they are considered a vulnerable population: they do not have the full capacity to consent to research and they may be more easily scared by certain procedures [12]. Hence, we can state that children can participate in research provided that such research does not burden the child and that there is respect for their growing autonomy and the right of a child to express their own values. In the case of full genome sequencing for children we are faced with a dilemma. On the one hand, the potential use of full genome sequences gathered, for example, at birth, used together with medical and other data from GPs or the public health system could provide an efficient and nearly limitless resource for researchers without putting any strain on the child his or herself. Thus this would satisfy the first requirement.
On the other hand, the fact of having one's genome sequenced may already be an infringement of a child's right to take this decision for herself. How does the duty of solidarity to participate in research that is cost effective and efficient and that does not burden the participant weigh up against the right to autonomously decide not to have one's genome sequenced?

A second, related issue is the status of raw sequenced data and the right to have a say. Raw sequenced data is data that is sequenced but not yet analyzed [1]. Some would argue it is value-free, as it is useless without further processing. Thus, the child's right to have a say only extends to the analysis and research use of these data. Hence, a newborn's DNA could be wholly sequenced provided that the parents or the child herself, when she grows older, are consulted about the possible research uses. In this approach, full genome sequencing and storage of the data is not so different from storage of extracted DNA in traditional biobanks. Others would argue that the sequencing itself is already one step too far and final and would therefore not be allowed for persons that cannot consent, such as children.

A third issue relates to the rights of the parents to decide on the sequencing of their child's genome for research. It is generally accepted that parents are allowed to consent to well described research on their children. A principle often quoted with regard to parental consent is that parents can consent for a child as long as this does not cut the child off from certain choices he or she would make in the future. Joel Feinberg called this the child's right to an open future [13]. But does the sequencing of the entire genome not violate this right? Is the decision to have a child participate in research involving whole genome sequencing trivial enough to be put on the same line with the many other decisions parents make for their children?

Another important question relates to the vast amount of data that is generated when an entire genome is sequenced for research. Inevitably incidental findings will occur that may be of relevance to the health of the child in question. When should such findings be returned to the child and/or the parents? Is a policy not to return any information valid in the case of pediatric participants? Should filters be used to make sure only the information relevant to the research is investigated and discovered? Can we adopt the recommendations regarding genetic testing of minors in this context [14]?

Corresponding author: Kristien Hens, PhD, Health, Ethics \& Society, P.O. Box 616, 6200 MD Maastricht, The Netherlands, Tel: + 31 (0) 43 3882547; Fax: + 31 (0) 43 3884171; M + 32 (0) 4782608 98; E-mail: k.hens@maastrichtuniversity.nl

Received November 12, 2011; Accepted November 15, 2011; Published November 18, 2011

Citation: Hens K (2011) Whole Genome Sequencing of Children's DNA for Research: Points to Consider. J Clinic Res Bioeth 2:106e. doi:10.4172/21559627.1000106e

Copyright: (c) 2011 Hens K. This is an open-access article distributed under the terms of the Creative Commons Attribution License, which permits unrestricted use, distribution, and reproduction in any medium, provided the original author and source are credited. 
Citation: Hens K (2011) Whole Genome Sequencing of Children's DNA for Research: Points to Consider. J Clinic Res Bioeth 2:106e. doi:10.4172/2155$9627.1000106 \mathrm{e}$

Page 2 of 2

I am sure many other and unexpected questions will arise when whole genome sequencing of children's DNA becomes more widely used in research. Now is the time to start thinking about those issues that can already be foreseen.

\section{References}

1. Health Council of the Netherlands (2010) The 'thousand-dollar genome': an ethical exploration. Monitoring Report Ethics and Health. The Hague: Centre for Ethics and Health.

2. Ng SB, Bigham AW, Buckingham KJ, Hannibal MC, McMillin MJ, et al. (2010) Exome sequencing identifies MLL2 mutations as a cause of Kabuki syndrome. Nat Genet 42: 790-793.

3. Stimulus Grant to Fund "Whole-Genome Sequencing" in Children with Autism. [http://www.childrenshospital.org/newsroom/Site1339/ mainpageS1339P1sublevel568.html]

4. Hens K, Levesque E, Dierickx K (2011) Children and biobanks: a review of the ethical and legal discussion. Hum Genet 130: 403-413.

5. Gurwitz D, Fortier I, Lunshof JE, Knoppers BM (2009) Research ethics. Children and population biobanks Science. 325: 818-819.

6. Caulfield T, McGuire AL, Cho M, Buchanan JA, Burgess MM, et al. (2008) Research Ethics Recommendations for Whole-Genome Research: Consensus Statement PLoS Biol 6:e73.
7. McGuire AL, Caulfield T, Cho MK (2008) Research ethics and the challenge of whole-genome sequencing Nat Rev Genet 9:152-156.

8. Robertson JA (2003) The $\$ 1000$ genome: ethical and legal issues in whole genome sequencing of individuals. Am J Bioeth: 3:W-IF1.

9. Netzer C, Klein C, Kohlhase J, Kubisch C (2009) New challenges for informed consent through whole genome array testing J Med Genet 46: 495-496.

10. President's Council on Bioethics (2008) President's Council on Bioethics: The Changing Moral Focus of Newborn Screening. Washington DC: President's Council on Bioethics.

11. Chadwick R, Berg K (2001) Solidarity and equity: new ethical frameworks for genetic databases Nat Rev Genet 2: 318-321.

12. Hens K, Nys H, Cassiman JJ, Dierickx K (2011) Risks, benefits, solidarity: a framework for the participation of children in genetic biobank research. $J$ Pediatr 158: 842-848.

13. Feinberg $J(1980)$ The Child's Right to an Open Future. In: Whose Child? Children's Rights, Parental Authority and State Power. Edited by Aiken WL, H. Plymouth: Plymouth: 124-153.

14. Borry P, Evers-Kiebooms G, Cornel MC, Clarke A, Dierickx K (2009) Genetic testing in asymptomatic minors: background considerations towards ESHG Recommendations. Eur J Hum Genet 17: 711-719. 